J. Perinat. Med. 15 (1987) 316

\section{Intrapartum fetal activity}

\author{
Shaul Yarkoni and John C. Hobbins
}

Section of Maternal-Fetal Medicine, Department of Obstetrics and Gynecology, Yale University School of Medicine, New Haven, Connecticut, U.S.A.

\section{Introduction}

Fetal movements have been studied throughout pregnancy. The evolution of these movements and its significance for fetal developmental progress and prognosis has been evaluated $[1,11]$. SADOVSKY considered fetal movements as an expression of fetal well-being. He suggested that decreased fetal movements are a sign of chronic fetal distress. He also showed that a pronounced decrease in movements, culminating in the cessation of fetal movements occurred in the terminal stages of fetal death in utero, although fetal heart beats were still audible for at least twelve hours after movements had ceased [10].

RichARDSON et al. [8] studied human fetal breathing movements before and during elective induction of labor in uncomplicated term pregnancies. They found that episodes of fetal breathing movements continued until the onset of the active phase of labor. At this stage, no episodes of fetal breathing movements were observed. They concluded that during active labor rapid irregular fetal breathing movements do not normally occur. PATRICK and Challis [7] measured fetal breathing movements during spontaneous labor at term in two patients. In both patients there was an increase in FBM during early labor, but they observed a reduction in FBM at the stage of active labor in one patient. BoylaN et al. [2] who studied 22

\section{Curriculum vitae}

ShaUl Yarkoni, M.D., born in 1941, was graduated from the Hebrew University Medical School, Jerusalem, Israel in 1968. Residency: Department of Obstetrics and Gynecology, Hadassah University Hospital, Jerusalem, Israel, $1970-1976$.

Following residency, he remained as a full-time faculty member until 1983. In 1981 he received the Dr. Arthur and Leah Felix Faculty Prize, for outstanding research in Obstetrics and Gynecology, the Hebrew University. From 1984 to present, he has been a fellow in perinatology, Yale University, New Haven, Connecticut.

Special interest: prenatal diagnosis by ultrasonography and fetal blood sampling.

patients during labor, found that fetuses spend $36 \%$ of their time making breathing movements antenataly but this decreased to less than $1 \%$ during labor. WHITTMANN et al. [12] who observed fetal activity by realtime ultra-sound for one hour in 25 patients in labor, found fetal respiratory movements in 13 patients, but reduced compared to the antenatal period. Fetal body and/or extremity movements were observed in all patients. Fetal movements were significantly correlated with contractions and fetal heart rate accelerations. 
The aim of this study is to describe normal intrapartum fetal movements, and breathing movements and to correlate them with fetal heart rate monitoring during labor, and with cord blood $\mathrm{pH}$ values and Apgar scores.

\section{Material and methods}

The study included 18 patients with singleton, normal, uncomplicated pregnancies of 37 to 42 weeks of gestation (average 39.8 weeks). All patients were in active labor (three or more uterine contractions per 10 minutes, with progressive cervical changes). The patients were invited to participate in the study after being given detailed information concerning the goal of realtime scanning of the fetus during labor and the experimental nature of the study. In twelve patients the cervix was dilated to between two and five $\mathrm{cm}$ and in six the cervical dilatation was between 6 and $9 \mathrm{~cm}$ at the start of the study. All fetuses were in vertex presentations. The head was in a $\leq 0$ station in eleven cases and in $\mathrm{a} \geq 1$ station in seven cases. No signs of fetal distress were seen in any of the fetuses (i.e. they had normal fetal heart patterns and clear amniotic fluid). All birth weights were between the 5th and 95th percentile limits for gestational age. Patients had their membranes ruptured at $5 \mathrm{~cm}$ or more cervical dilatation. Continuous ultrasound scanning was performed in each patient for one hour using a realtime linear array scanner (ADR, $4000 \mathrm{~S} /$ LC, Tempe, AR) equipped with a $3.5 \mathrm{MHZ}$ transducer. The transducer was placed on the maternal abdomen so that the fetal thorax, part of the head, upper abdomen and part of the fetal limbs could be visualized at the same time. The ultrasound monitoring was stored by a video tape recorder. The fetal heart rate (FHR) and uterine contractions (UC) were also simultaneously recorded using the Advanced medical systems 1M-88 (Litton Datamedix) cardiotocograph, and synchronized with the fetal behavior. The cord venous blood $\mathrm{pH}$ was ascertained after delivery used a blood gas analyzer ( $\mathrm{ABL}_{3}$ Radiometer, Copenhagen). Apgar scores at one and five minutes after delivery were used to evaluate the newborn in the immediate postpartum period. The videotape recording of FM and FBM together with the FHR and UC monitorings were reviewed later in a synchronous manner using a stop watch to measure precisely the duration of FM and FBM. The magnitude of FHR accelerations associated with FM were also measured and correlated with strong fetal movements (intense body or limb movements) or weak fetal movements (weak body movements, isolated head or limb movements).

\section{Results}

All patients had normal, uncomplicated labors. Cord venous blood $\mathrm{pH}$ was $>7.25$, and Apgar scores of $\geq 7$ at 5 minutes were recorded in all newborns.

Fetal movements (FM): The average percentage incidence of fetal movements (the percentage of observation time during which fetal movements were observed) was 19.5 per cent, the range

Table I. Percentage incidence of fetal movements (FM), fetal breathing movements (FBM), and total fetal activity (TFA).

\begin{tabular}{|c|c|c|c|}
\hline Patient & $\begin{array}{l}\text { FM } \\
(\%)\end{array}$ & $\begin{array}{l}\text { FBM } \\
(\%)\end{array}$ & $\begin{array}{l}\text { TFA } \\
(\%)\end{array}$ \\
\hline 1 & 28.0 & 15.0 & 43.0 \\
\hline 2 & 10.3 & 20.1 & 30.4 \\
\hline 3 & 28.6 & 10.1 & 38.7 \\
\hline 4 & 10.1 & 4.4 & 14.5 \\
\hline 5 & 15.6 & 27.1 & 42.7 \\
\hline 6 & 21.5 & 9.2 & 30.7 \\
\hline 7 & 27.2 & 8.4 & 25.6 \\
\hline 8 & 21.4 & 5.2 & 26.6 \\
\hline 9 & 31.3 & 0.0 & 31.3 \\
\hline 10 & 17.3 & 10.4 & 29.0 \\
\hline 11 & 14.4 & 12.2 & 26.0 \\
\hline 12 & 21.2 & 0.0 & 21.2 \\
\hline 13 & 12.9 & 6.8 & 19.7 \\
\hline 14 & 25.5 & 5.0 & 30.5 \\
\hline 15 & 24.3 & 3.9 & 28.2 \\
\hline 16 & 18.7 & 12.6 & 31.3 \\
\hline 17 & 12.1 & 2.1 & 14.2 \\
\hline 18 & 11.0 & 1.1 & 12.1 \\
\hline mean $\pm \mathrm{SD}$ & $19.5 \pm 6.9$ & $8.5 \pm 7.1$ & $27.5 \pm 8.9$ \\
\hline
\end{tabular}




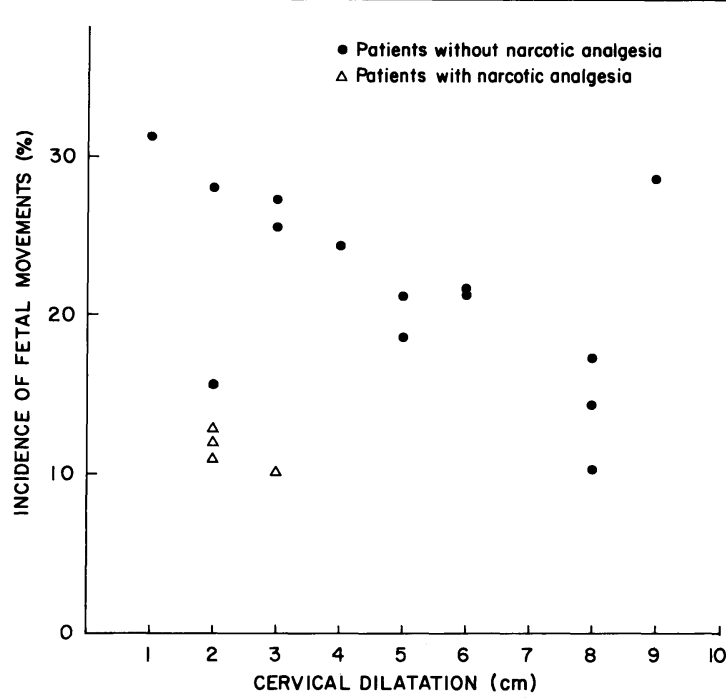

Figure 1. Percentage incidence of fetal body movements against cervical dilation.

being between 10.1 per cent and 28.6 per cent. The average duration of a single movement was 49.4 seconds and the range was from 27 to 69 seconds (table I). In fourteen patients who were not under any narcotic analgesia at the time of the study, the percentage incidence of FM had a tendency to decrease linearly as the cervical dilatation increased (figure 1). In the remaining four patients who were under narcotic analgesia the percentage incidence of fetal body movement was 11.5 per cent. These patients were treated with $40 \mathrm{mg}$ of alphaprodine hydrochloride (Nisentil, Roche) given subcutaneously 30 to 120 minutes before the beginning of the study. In four patients who were at the same stage of labor, but without alphaprodine hydrochloride medication, the percentage incidence was significantly higher, 24.1 per cent (figure 1).

Fetal breathing movements (FBM): In 16 of the 18 patients FBM was observed. The percentage incidence ranged from 0 to 27 per cent with an average of 8.5 per cent. The average duration of a single breathing epidsode was 57 seconds and the range was between 22 and 84 seconds. Breathing movements mainly occurred between uterine contractions. In the patients who were under narcotic analgesia, the mean PI of FBM was only 3.6 per cent, while in those without

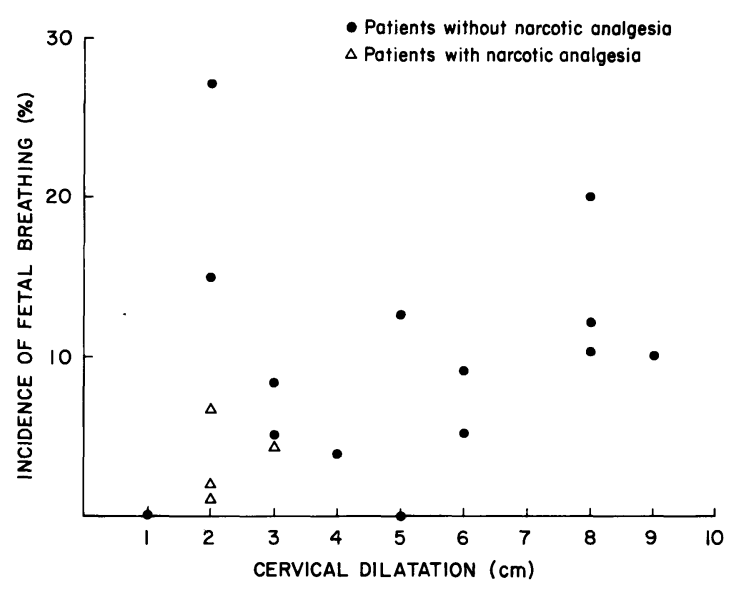

Figure 2. Percentage incidence of fetal breathing movements against cervical dilation.

narcotic analgesia the mean was 9.9 per cent. No significant changes in the PI of FBM were found throughout labour (figure 2).

Total fetal activity (TFA): The percentage incidence of TFA ranged from 12.1 to 43.0 per cent, with a mean of $27.5 \pm 8.9$ per cent (table II). Fetuses of mothers with narcotic analgesia,

Table II. Total fetal activity (TFA) and fetal outcome (cord blood pH and Apgar score).

\begin{tabular}{llll}
\hline Patient & $\begin{array}{l}\text { TFA } \\
(\%)\end{array}$ & $\begin{array}{l}\text { Cord blood } \\
\text { pH }\end{array}$ & $\begin{array}{l}5^{\prime} \text { Apgar } \\
\text { score }\end{array}$ \\
\hline 1 & 43.0 & 7.29 & 9 \\
2 & 30.4 & 7.37 & 9 \\
3 & 38.7 & 7.30 & 9 \\
4 & 14.5 & 7.34 & 8 \\
5 & 42.7 & 7.38 & 9 \\
6 & 30.7 & 7.26 & 9 \\
7 & 25.6 & 7.29 & 9 \\
8 & 26.6 & 7.32 & 9 \\
9 & 31.3 & 7.26 & 9 \\
10 & 29.0 & 7.38 & 9 \\
11 & 26.0 & 7.29 & 9 \\
12 & 21.6 & 7.27 & 9 \\
13 & 19.7 & 7.27 & 9 \\
14 & 30.5 & 7.28 & 9 \\
15 & 28.2 & 7.33 & 7 \\
16 & 31.3 & 7.30 & 9 \\
17 & 14.2 & 7.31 & 7 \\
18 & 12.1 & 7.29 & 9 \\
\hline mean \pm SD & $27.5 \pm 8.9$ & $7.3 \pm 0.04$ & $8.7 \pm 0.6$ \\
\hline
\end{tabular}




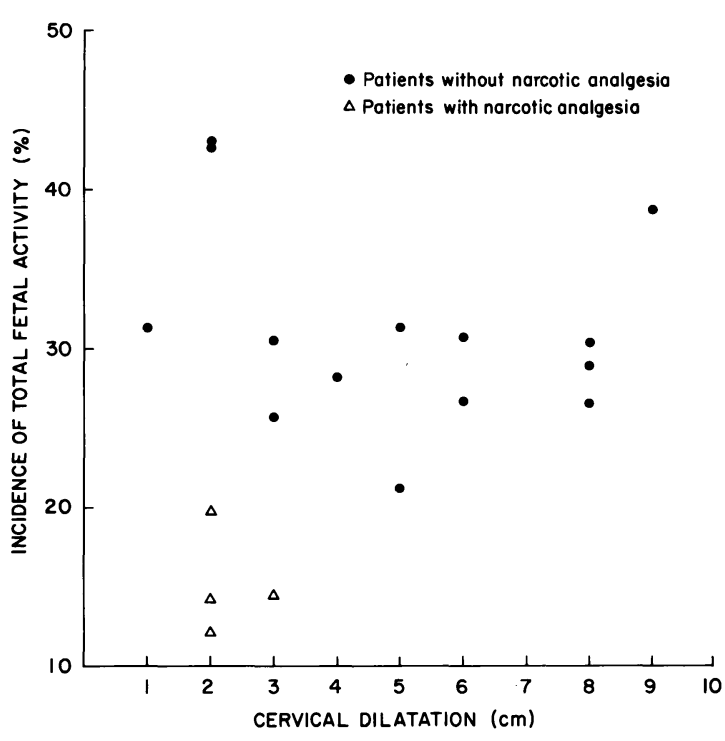

Figure 3. Percentage incidence of total fetal activity against cervical dilatation.

showed lower PI of TFA than these of mothers without narcotic analgesia, the mean being 15.1 and 31.1 per cent respectively (figure 3 ).

Fetal heart rate (FHR): Fetal heart rate baselines were between 135 and $160 \mathrm{bpm}$ and the variability ranged from 5 to $20 \mathrm{bpm}$. All body movements were associated with accelerations of 14 to $27 \mathrm{bpm}$. Stronger body movements such as rolling or strong kicking were associated with higher FHR accelerations. For the strong movements FHR accelerations were 15-40 bpm and for the weak movements, such as isolated limb or head movement they were $5-15 \mathrm{bpm}$. No FHR accelerations were observed during isolated fetal breathing movements, which were not accompanied by FM.

\section{Discussion}

Fetal movements (FM) and fetal breathing movements (FBM) are indicators of fetal wellbeing. These fetal activities, with FHR reactivity, fetal tone and amniotic fluid volume constituted the biophysical profile of the fetus which has been widely used to measure fetal vitality.
In this study we followed the fetuses during active labor. All the 18 fetuses were normal without signs of asphyxia, and demonstrated good heart rate reactivity (two or more fetal heart rate accelerations of at least $15 \mathrm{bpm}$ for at least 15 seconds associated with FM in a 20-minute period). The finding that all fetal movements were associated with FHR accelerations could suggest that FHR acceleration which are not associated with uterine contractions most probably reflect fetal movements. This assumption is well correlated with the findings of KREBS et al. These authors found that there is a good correlation between the number of sporadic accelerations (which are not associated with uterine contractions) during labor and fetal outcome. The more accelerations, the lower the incidence of Apgar scores of $<7$ at 1 minute and at 5 minutes [5]. To date, there is no report that we are aware of in the literature which deals with the correlation between the vigor of FM and the magnitude of FHR accelerations. We found that strong FM were associated with higher FHR accelerations. This might suggest that a stronger stimulus originating in the central nervous system (CNS) is responsible for the stronger FM and the higher FHR accelerations.

RoBERTS et al. [9] who studied fetal movements in the third trimester of pregnancy, found that the percentage incidence of FM was 18, the range over a 24-hour period being from 11 to 26 per cent. Our findings of a 19.5 per cent incidence of FM with a range from 10.1 per cent to 28.6 per cent, are closely related to those of Roberts and colleagues in the third trimester. However, we found a linear decrease in FM as labor progressed. EHRENSTROM [4] and WoOD et al. [13] found a decrease in FM during the third trimester of pregnancy as it were perceived by the mother. They suggested that the finding could be explained by the relative decrease of amniotic fluid and therefore, the decrease of free space in the amniotic sac. This hypothesis might be questioned. Although during active labor and especially after a rupture of membranes, less amniotic fluid and less free space is available for the fetus, a decrease in the 
amplitude rather than a decrease in the frequency of the movements, might be expected. It is interesting to note that fetuses of mothers who were given narcotics in labor show significantly decreased movements and breathing movements. However, because of the small number of patients no definite conclusion can be drawn.

RICHARDSON et al. [8] studied human FBM before and during induction of labor in uncomplicated term pregnancies. Fetal breathing movements were observed for a one hour control period prior to induction. Fetal breathing activity was observed until the onset of labor. Following the onset of labor, no episodes of normal FBM were observed. They examined the effects of epidural anesthesia, ruptured membranes, oxytocin infusion, maternal blood glucose and maternal venous blood gases and could not find any explanation of the arrest of FBM during active labor. The fetuses all had a good outcome and the authors concluded that during active labor rapid irregular FBM do not normally occur.

PATRICK and Challis [7] happened to measure FBM during spontaneous normal delivery in two cases. In both patients there was an increase in FBM in early labor which was not related to maternal meals. The first patient was not followed further. In the second patient,
FBM fell to very low levels, when she developed active labor. At this stage the study was stopped. Both patients delivered healthy fetuses with very good Apgar scores. CASTLE and TuRnBaLL [3] studied FBM in preterm fetuses in 54 patients before 34 weeks gestation. In 19 or 20 pregnancies with no detectable fetal breathing (during 45 minutes of observation), delivery occurred within 48 hours, whereas in 25 of 34 with fetal breathing pregnancy continued for a week or more. Of the remaining nine, seven had had spontaneous membrane rupture. They suggested that prostaglandin $\mathrm{F}_{2}$-alpha, which is apparently originating from the placenta in true labor, can inhibit FBM.

In our present study we observed FBM in 16 of the 18 patients. The mean percentage incidence of FBM in labor was 8.5 per cent. Patrick et al. [6] and Roberts et al. [9] found that the percentage incidence of FBM over a 24 hour period in the third trimester of pregnancy was 31 per cent. Unlike the results of Richardson et al. [8] we observed FBM in most of the patients, even during the active phase of labor. This might indicate the autonomous nature of FBM. The results of this study indicate that the normal fetus continues with its "routine" activities during labor. These fetal activities may prove helpful in the intrapartum assessment of the fetus. This hypothesis is currently being tested prospectively by our group.

\section{Summary}

Fetal activity throughout pregnancy has been thoroughly studied. Relatively little informations regarding intrapartum fetal activity is available. RICHARDSON et al. [8] found no fetal respiratory movements. While BOYLAN et al. [2] and WhITTMANN et al. [12] reported decreased fetal breathing movements in active labor. This study was undertaken to evaluate the normal pattern of fetal activity in labor. Fetal movements (FM) and fetal breathing movements (FBM) were monitored by realtime ultrasound during active labor at term. The incidence of FM and FBM were measured in 18 fetuses. Results were correlated with simultaneous fetal heart rate (FHR) changes, postpartum cord blood $\mathrm{pH}$ and Apgar score. Recordings were made for one hour on every patient.
The mean percentage incidence (PI) of FM was 19.5 per cent (range: $10.1-28.6$ percent) and FBM was 8.5 per cent (range: $0-27$ percent). All FM were associated with FHR accelerations, stronger movements were associated with higher FHR accelerations. No FHR accelerations were observed with FBM alone, unless accompanied by fetal movement. The lowest PI of total fetal activity (TFA, i. e. FM plus FBM) was 12.1 per cent. Movements decreased as labor progressed, while FBM remained unaltered. All newborns had cord venous blood $\mathrm{pH}$ of $>7.25$ and Apgar scores of $\geq 7$, at five minutes. Our data suggest that in the normal uncompromised fetus, FM and FBM continue during labor at term. However, while FM tends to decrease as labor progresses, FBM tends to be constant throughout labor. 
This finding might indicate the autonomous nature of FBM. The finding that stronger FMs are associated with higher FHR acceleration might suggested that a stronger stimulus originating in the central nervous system is responsible for this association. These findings indicate that the normal fetus continues with its "routine" activities during labor. These fetal activities may prove helpful in the intrapartum assessment of fetal well-being.

Keywords: Fetal breathing, fetal movements, intrapartum.

\section{Zusammenfassung}

\section{Fetale Aktivität sub partu}

Die fetale Aktivität während der Schwangerschaft wurde hinreichend untersucht. Relativ wenige Informationen stehen jedoch bezüglich der fetalen Aktivität sub partu zur Verfügung. Während RichaRDSON et al. [8] keine fetalen Atembewegungen registrierten, berichten BoYLAN et al. [2] und WhitTMANN et al. [12] über eine Abnahme der fetalen Thoraxexkursionen unter der Geburt. Ziel unserer Studie war die Untersuchung des normalen, fetalen Aktivitätsmusters sub partu. Mit einem Realtime-Scanner wurden die fetalen Bewegungen und Atemexkursionen bei insgesamt 18 Feten am Termin sub partu registriert. Die Ergebnisse wurden mit simultanen Veränderungen der fetalen Herzfrequenz, dem $\mathrm{pH}$ im Nabelblut sowie dem Apgar-Score korreliert. Die Aufzeichnungen pro Patient gingen jeweils über eine Stunde.

Die mittlere prozentuale Inzidenz (PI), bezogen auf den Beobachtungszeitraum, betrug für die fetalen Bewegungen $19,5 \%(10,1-28,6 \%)$ und für die Atemexkursionen $8,5 \%(0-27 \%)$. Alle fetalen Bewegungen waren mit Akzelerationen der fetalen Herzfrequenz assoziiert, wobei heftigere Bewegungen stärkere Akzelerationen auslö- sten. Atemexkursionen ohne Bewegungen veränderten das Akzelerationsmuster nicht. Die niedrigste prozentuale Inzidenz der gesamten fetalen Aktivität (Bewegungen plus Atemexkursionen) betrug 12,1\%. Mit zunehmendem Geburtsfortschritt nahmen die fetalen Bewegungen $a b$; die Inzidenz der Atemexkursionen veränderte sich nicht. Alle Neugeborenen hatten einen Nabelvenen-pH $>7,25$ und einen Apgar, Score $\geq 7$ nach 5 Minuten. Unsere Ergebnisse zeigen, da $B$ man beim nicht beeinträchtigten, normalen Feten am Termin unter der Geburt Bewegungen und Atemexkursionen nachweisen kann. Während jedoch die fetalen Bewegungen abnehmen, scheinen die Atemexkursionen sub partu konstant zu bleiben, was als Hinweis auf den autonomen Charakter der fetalen Atembewegungen zu werden ist. Die Tatsache, daß heftige Bewegungen mit höhren Akzelerationen der Herzfrequenz einhergehen, kann bedeuten, $\mathrm{da} B$ ein stärkerer Stimulus aus dem ZNS für diese Assoziation verantwortlich ist. Wir konnten zeigen, daß der normale Fet seine „Routine-Aktivitäten“ sub partu fortsetzt. Fetale Bewegungen und Atemexkursionen können als Parameter für die intrapartuale Beurteilung des fetalen Zustands herangezogen werden.

Schlüsselwörter: Fetale Atemsexkursionen, fetale Bewegungen, sub partu.

\section{Résumé}

\section{Activité du fetus au cours du travail}

Activité fotale a été largement étudiée tout au long de la grossesse. Mais on dispose de relativement peu d'informations sur l'activité fotale au cours du travail. RichARDSON et al. [8] n'ont pas trouvé de mouvement respiratoire fotal. Alors que BoYLAN et al. [2] et WHITTMANN et al. [12] ont rapporté une diminution des mouvements respiratoires fotaux au cours du travail. On a entrepris cette étude afin d'évaluer le modéle normal de l'activité fœtale au cours tu travail. Les mouvements actifs (M. A.) et les mouvements respiratoires du fœtus (M. R.) ont été surveillés par échographie en temps réel au cours tu travail à terme. On a mesuré l'incidence des M.A. et des M.R. chez 18 fœtus. On a corrélé les résultats avec les modifications simultanées du rythme cardiaque fotal (R.C. F.), avec le PH du sang du cordon après l'accouchement et avec le score d'Apgar. Les enregistrements ont été réalisés pendant une heure pour chaque patiente.
L'incidence moyenne en pourcentage (P. I.) de M. A. est de 19,5 pour cent (écarts de 10,1 à 28,6 pour cent) et de M. R. de 8,5 pour cent (écarts de 0 à 27 pour cent). Tous les M.A. s'accompagnent d'accélérations du R.C.F. les mouvements plus intenses sont accompagnés d'accélérations plus importantes. Il n'a pas été observé d'accélérations du R.C.F. avec des M.R. isolés, mais on en a observé lorsque les M. R. sont associés avec des mouvements actifs. Le P.I. le plus bas d'activité fotale totale (T. F. A., c'est-à-dire P. A. plus M. R.) est de 12,1 pour cent. Les mouvements diminuent à measure que le travail progresse, tandis que les M.R. demeurent inchangés. Tous les nouveaux-nés ont eu un $\mathrm{PH}$ veineux au cordon $>7,25$ et un score d'Apgar $\geq 7$, à cinq minutes. Nos données suggèrent que chez le fœtus normal sain, les M. A. et les M. R. se poursuivent au cours du travail à terme. Néanmoins, alors que les M.A. ont tendance à diminuer à mesure que le travail progresse, les M.R. ont tendance à rester constant au cours du travail. Ce 
fait pourrait indiquer la nature autonome des M.R. Le fait que des M.A. plus intenses s'accompagnent d'accélérations plus importantes du R.C.F. pourrait suggérer qu'un stimulus plus intense ayant son origine au niveau du système nerveux central est responsable de cette association. Ces données indiquent que le fœtus normal poursuit ses activités «de routine» au cours du travail. Ces activités fœtales peuvent être utiles dans l'estimation du bien être fotal au cours du travail.

Mots-clés: Intrapartum, movements fœtaux, respiration fœtale.

\section{References}

[1] Birnholz JC, JC Stephens, M Faria: Fetal movements patterns: A possible means of defining neurologic developmental milestones in utero. Am J Roentgenol 130 (1978) 537

[2] Boylan P, PJ LeWIS: Fetal breathing in labor. Obstet Gynecol 56 (1980) 35

[3] Castle BM, AC Turnbull: The presence or absence of fetal breathing movements predicts the outcome of preterm labour. Lancet I (1983) 471

[4] Ehrstrom C: Fetal movement monitoring in normal and high risk pregnancy. Acta Obstet Gynecol Scand 80 (S) (1979) 1

[5] Krebs HB, RE Petres, LJ Dunn, PJ Smith: Intrapartum fetal heart rate monitoring. VI. Prognostic significance of accelerations. Am J Obstet Gynecol 142 (1982) 297

[6] Patrick J, K Campbell, L Carmichael, R NaTALE, B RichardSON: Patterns of human fetal breathing during the last 10 weeks of pregnancy. Obstet Gynecol 56 (1980) 24

[7] Patrick J, J Challis: Measurement of human fetal breathing movements in healthy pregnancies using a real-time scanner. Semin Perinatol 4 (1980) 275

[8] Richardson B, R Natale, J Patrick: Human fetal breathing activity during induced labour at term. Am J Obstet Gynecol 133 (1979) 247
[9] Roberts AB, D Little, D CoOper, S CAMpbell: Normal patterns of fetal activity in the third trimester. Br J Obstet Gynaecol 86 (1979) 4

[10] SADOvsky E: Antepartum monitoring of fetal movements. Modern management of high-risk pregnancy (edited by NH Lauerson). Plenum, New York, 1983

[11] Sadovsky E, N Laufer, JW Allen: The incidence of different types of fetal movement during pregnancy. Br J Obstet Gynaecol 86 (1979) 10

[12] Whittmann BK, BM Davison, E Lyons, J Frohlich, ME Towell: Realtime ultrasound observation of fetal activity in labor. Br J Obstet Gynaecol 86 (1979) 278

[13] Wood C, M Gilbert, A O'ConNor, WAW WaLTERS: Subjective recording of fetal movements. $\mathrm{Br}$ J Obstet Gynaecol 86 (1979) 836

Received December 5, 1985. Revised May 2, 1986. Accepted May 22, 1986.

Shaul Yarkoni, M. D.

Department of Obstetrics \& Gynecology

Yale University School of Medicine

333 Cedar Street, P. O. Box 3333

New Haven, CT 06510, U.S. A. 